\title{
Prognostic Indices of Survivability in Caesarean Operated Buffaloes
}

\author{
B. G. Chaudhary, C. F. Chaudhari*, R. K. Chaudhari, T. V. Sutaria, \\ B. N. Suthar, H. C. Nakhashi, P. M. Chauhan, K. K. Gurjar, S. H. Raval, \\ S. S. Patel and M. M. Pandya
}

\author{
Department of Veterinary Gynaecology and Obstetrics, College of Veterinary \\ Science and Animal Husbandry, Sardarkrushinagar Dantiwada Agricultural University, \\ Sardarkrushinagar, Gujarat, India \\ *Corresponding author
}

\section{Keywords}

Buffalo, Caesarean section, Dystocia,

Oxidative stress

parameters,

Uterine torsion

Article Info

Accepted:

18 November 2020

Available Online:

10 December 2020

\begin{abstract}
A B S T R A C T
The present study was conducted on 12 uterine torsion affected Mehsana buffaloes. The buffaloes were equally divided in to two groups and surgically managed to relive dystocia with or without supplementation of ascorbic acid. All the buffaloes were monitored for survivability up to 30 days post-caesarean section. Irrespective of the supplementation of ascorbic acid, buffaloes survived up to 30 days post operatively were included in group I $(n=7)$, While buffaloes not survived up to 30 days post-operatively were included in group II $(n=5)$. Previous handling of the cases in field and duration of illness were significantly $(\mathrm{P}<0.05)$ associated with survivability of buffaloes. The mean TAC concentration was significantly $(\mathrm{P}<0.05)$ increased after $48 \mathrm{~h}$ and $96 \mathrm{~h}$ of caesarean operation in group I. The MDA concentration was significantly $(\mathrm{P}<0.05)$ reduced at $96 \mathrm{~h}$ of caesarean operation in the group I than group II. The ALT concentration was significantly $(\mathrm{P}<0.05)$ reduced after $48 \mathrm{~h}$ as compared to its level before caesarean section in group I. Concentration of cortisol was also significantly $(\mathrm{P}<0.05)$ reduced after the caesarean operation in group I. In conclusion, total antioxidant capacity, malondialdehyde and cortisol can be used as prognostic indicators in caesarean operated buffaloes.
\end{abstract}

\section{Introduction}

Dystocia is one of the economically important reproductive disorder reported in various domestic animals viz., buffalo (Dabas et al., 2013), cow (Khudhair et al., 2020), mare (Dabas et al., 2014; Fotariya et al., 2020), goat (Patel et al., 2020), dog and cat (Traas, 2008). Among different types of dystocia, uterine torsion has been reported to be a major cause of maternal dystocia in buffaloes
(Amin et al., 2011) which is fatal to both fetus and the dam. Critical evaluation of uterine torsion in buffaloes revealed that it is the single largest cause of maternal dystocia in referral cases, its incidence ranges from 52 to $70 \%$, and affects buffaloes mostly towards terminal gestation (Purohit and Gaur, 2014). There are different ways to manage dystocia in buffaloes viz., mutation operations alone (Singh et al., 2013) or with forced traction (Dabas et al., 2013), fetotomy (Gupta et al., 
2017) and caesarean section (Wani et al., 2018). Among the above methods, caesarean section in buffaloes is an emergency operative procedure, used as a last remedy to treat the cases of dystocia and for the delivery of fetal monsters or for delivery of fetuses with anomalies (Wani et al., 2018). The operation is considered as surgery of highest magnitude due to extent of stress involved both due to dystocia and surgical trauma (Cox, 1987).

Evaluation of oxidative stress and antioxidant enzymes must remain the keystone of veterinary obstetrical research because it is quantitative information which can gives better understanding about the causes of oxidative stress (Bansal et al., 2011) and status of animal health during oxidative stress (Thangamani et al., 2019). Difficult parturition causes the stress which affects on the normal hematological and biochemical parameters. Elevated blood plasma fibrinogen, Blood urea nitrogen (BUN) and creatinine concentrations and lower plasma proteins in delayed cases of dystocia indicated progression towards severe inflammation, stress and possibly peritoneal adhesion formation (Singh et al., 2017). The dystocia cases registered at the referral hospitals are mostly delayed ones and previously handled in the field which might cause additional stress and tissue damage. Survivability of the dam in such cases is always compromised and could be managed by understanding of historical perspectives and blood indices. Looking to the above facts, the present study has been conducted to understand prognostic indicators of survivability in caesarean operated buffaloes.

\section{Materials and Methods}

Twelve uterine torsion affected Mehsana buffaloes which required caesarean section to relieve dystocia were selected in the present investigation. Detailed history with respect to parity, duration of illness, previously handled in the field, etc. were recorded and obstetrical examination was performed. All the animals were randomly divided in two equal groups and surgically managed to relive dystocia with or without supplementation of ascorbic acid one hour before and 24 hours after caesarean section. Blood samples were collected immediately before caesarean section ( 0 hour) and thereafter postoperatively at 48 hours and 96 hours. Haemoglobin (Hb, g/dL) and packed cell volume (\%) were analyzed by haemato analyzer (Exigo). Total antioxidant capacity (TAC, mmol/L), malondialdehyde (MDA, $\mathrm{mmol} / \mathrm{L}$ ), super oxide dismutase (SOD, units $/ \mathrm{ml}$ ) and cortisol ( $\mathrm{ng} / \mathrm{ml})$ were analyzed by using commercially available colorimetric assay kit manufactured by Puregene, Genetrix Biotech Asia Pvt. Ltd. All the other serum biochemicals were estimated with the help of different kits manufactured by Agappe Diagnostics Ltd. using RX-50V Biochemistry Analyzer (Microlab, India).

Irrespective of the supplementation of ascorbic acid, buffaloes survived up to 30 days were included in survived group (Group $\mathrm{I}, \mathrm{n}=7$ ) and buffaloes not-survived up to 30 days were included in died group (Group II, $\mathrm{n}=5$ ). Haemato-biochemical parameters were analysed statistically by two-way repeated measures ANOVA with terms for group, time period and their interactions. Association of history and obstetrical parameters with the survivability of dam were analyzed by chisquare test. Data analysis was done with SPSS software (IBM® ${ }^{\circledR}$ SPSS® statistics, version 20.0).

\section{Results and Discussion}

\section{History and obstetrical parameters}

In the present study, significant association between handling of dystocia at field 
$(\mathrm{P}=0.003)$ and dam survivability was found (Table 1). All the buffaloes which were not previously handled in the field were survived; while, $83.33 \%$ buffaloes previously handled in the field were died. Duration of illness was also associated significantly $(\mathrm{P}=0.007)$ with the survivability of dam. The survival rate was higher in buffaloes suffered since $<24 \mathrm{~h}$ of illness $(83.33 \%)$ as compared to buffaloes suffered since> $24 \mathrm{~h}(66.67 \%)$ which was in agreement with Murthy et al., (1999) and Prabhakar et al., (2002). Low survivability in delayed casein the present study could be due to stress of dystocia (Dhindsa et al., 2019), endotoxaemic shock, haemorrhage, edema of uterus and dehydration (Sloss, 1974). All the other historical and obstetrical parameters were non-significantly associated with survivability of dam.

Table.1 Association of history and obstetrical parameters with survivability in caesarean operated Mehsana buffaloes

\begin{tabular}{|c|c|c|c|c|}
\hline \multicolumn{2}{|c|}{ Particulars } & \multirow{3}{*}{$\begin{array}{c}\begin{array}{c}\text { Survived (n=7) } \\
\text { Group I }\end{array} \\
50 \%(1) \\
60 \%(6)\end{array}$} & \multirow{3}{*}{$\begin{array}{c}\text { Died (n=5) } \\
\text { Group II } \\
50 \%(1) \\
40 \%(4)\end{array}$} & \multirow{3}{*}{$\begin{array}{c}\text { Significance } \\
\begin{array}{c}\chi^{2}=0.068, \text { d.f. }=1 \\
p=0.793\end{array}\end{array}$} \\
\hline \multirow{2}{*}{ Parity } & Primiparous $(n=2)$ & & & \\
\hline & $\begin{array}{c}\text { Pluriparous } \\
(\mathrm{n}=10)\end{array}$ & & & \\
\hline \multirow{2}{*}{$\begin{array}{c}\text { Duration of illness } \\
\text { (hours) }\end{array}$} & $<24(\mathrm{n}=6)$ & $83.33 \%(5)$ & $16.67 \%(1)$ & \multirow{2}{*}{$\begin{array}{c}\chi^{2}=7.363, \text { d.f }=1 \\
p=0.007\end{array}$} \\
\hline & $>24(\mathrm{n}=6)$ & $33.33 \%(2)$ & $66.67 \%(4)$ & \\
\hline \multirow[t]{4}{*}{ Off feed since (days) } & No $(n=3)$ & $100 \%(3)$ & $0 \%(0)$ & \multirow{4}{*}{$\begin{array}{c}\chi^{2}=4.800, \text { d.f. }=3 \\
p=0.187\end{array}$} \\
\hline & $1(n=4)$ & $50 \%(2)$ & $50 \%(2)$ & \\
\hline & $2(n=4)$ & $25 \%(1)$ & $75 \%(3)$ & \\
\hline & $3(n=1)$ & $100 \%(1)$ & $0 \%(0)$ & \\
\hline \multirow{2}{*}{$\begin{array}{l}\text { Previously handled in } \\
\text { field }\end{array}$} & Yes $(n=6)$ & $16.67 \%(1)$ & $83.33 \%(5)$ & \multirow{2}{*}{$\begin{array}{c}\chi^{2}=8.571, \text { d.f. }=1 \\
p=0.003\end{array}$} \\
\hline & No $(n=6)$ & $100 \%(6)$ & $0 \%(0)$ & \\
\hline \multirow[t]{2}{*}{ Rolling given at clinic } & Yes $(n=10)$ & $60 \%(6)$ & $40 \%(4)$ & \multirow{2}{*}{$\begin{array}{c}\chi^{2}=0.068, \text { d.f. }=1 \\
p=0.793\end{array}$} \\
\hline & No $(n=2)$ & $50 \%(1)$ & $50 \%(1)$ & \\
\hline \multirow[t]{3}{*}{ No. of rolling } & $1(n=2)$ & $100 \%(2)$ & $0 \%(0)$ & \multirow{3}{*}{$\begin{array}{c}\chi^{2}=1.566, \text { d.f. }=2 \\
p=0.459\end{array}$} \\
\hline & $2(n=3)$ & $66.67 \%(2)$ & $33.33 \%(1)$ & \\
\hline & $3(n=2)$ & $100 \%(2)$ & $0 \%(0)$ & \\
\hline \multirow[t]{2}{*}{ Site of torsion } & Pre-cervical $(n=3)$ & $100 \%(3)$ & $0 \%(0)$ & \multirow{2}{*}{$\begin{array}{c}\chi^{2}=2.857, \text { d.f. }=1 \\
p=0.091\end{array}$} \\
\hline & $\begin{array}{l}\text { Post-cervical } \\
\quad(n=9)\end{array}$ & $44.44 \%(4)$ & $55.56 \%(5)$ & \\
\hline \multirow[t]{2}{*}{ Side of torsion } & Right $(n=10)$ & $60 \%(6)$ & $40 \%(4)$ & \multirow{2}{*}{$\begin{array}{c}\chi^{2}=0.068, \text { d.f }=1 \\
p=0.793\end{array}$} \\
\hline & Left $(n=2)$ & $50 \%(1)$ & $50 \%(1)$ & \\
\hline \multirow[t]{3}{*}{ Degree of torsion } & $180-270(\mathrm{n}=5)$ & $40 \%(2)$ & $60 \%(3)$ & \multirow{3}{*}{$\begin{array}{c}\chi^{2}=2.949, \text { d.f. }=2 \\
p=0.228\end{array}$} \\
\hline & $270-360(n=3)$ & $100 \%(3)$ & $0 \%(0)$ & \\
\hline & $>360(n=4)$ & $50 \%(2)$ & $50 \%(2)$ & \\
\hline \multirow[t]{2}{*}{ Sex of calf } & Male $(n=10)$ & $60 \%(6)$ & $40 \%(4)$ & \multirow{2}{*}{$\begin{array}{c}\chi^{2}=0.068, \text { d.f. }=1 \\
p=0.793\end{array}$} \\
\hline & Female $(n=2)$ & $50 \%(1)$ & $50 \%(1)$ & \\
\hline \multirow[t]{2}{*}{ Fetus livability } & Live $(n=1)$ & $100 \%(1)$ & $0 \%(0)$ & \multirow{2}{*}{$\begin{array}{c}\chi^{2}=0.779, \text { d.f. }=1 \\
p=0.377\end{array}$} \\
\hline & Dead $(n=11)$ & $54.55 \%(6)$ & $45.45 \%(5)$ & \\
\hline \multirow[t]{2}{*}{ Size of fetus } & Normal $(n=6)$ & $83.33 \%(5)$ & $16.67 \%(1)$ & \multirow{2}{*}{$\begin{array}{c}\chi^{2}=3.086, \text { d.f }=1 \\
p=0.079\end{array}$} \\
\hline & Overweight $(\mathrm{n}=6)$ & $33.33 \%(2)$ & $66.67 \%(4)$ & \\
\hline
\end{tabular}


Table. 2 The oxidative stress profile and haemato-biochemical parameters in survived and died Mehsana buffaloes

\begin{tabular}{|c|c|c|c|c|c|c|c|}
\hline \multirow[t]{2}{*}{ Parameters } & \multirow[t]{2}{*}{$\mathbf{G}$} & \multicolumn{3}{|c|}{ Time (h) } & \multicolumn{3}{|c|}{ P-value } \\
\hline & & $\mathbf{0}$ & 48 & 96 & Time & Group & $\mathbf{T} * \mathbf{G}$ \\
\hline \multirow{2}{*}{$\begin{array}{c}\text { TAC } \\
(\mathrm{mmol} / \mathrm{L})\end{array}$} & I & $0.89 \pm 0.12_{\mathrm{a}}$ & $1.37 \pm 0.18_{b}$ & $1.34 \pm 0.12^{\mathrm{A}}$ & \multirow[t]{2}{*}{0.001} & \multirow[t]{2}{*}{0.239} & \multirow[t]{2}{*}{0.113} \\
\hline & II & $0.82 \pm 0.14_{b}$ & $1.17 \pm 0.22_{\mathrm{a}}$ & $0.87 \pm 0.14_{b}^{B}$ & & & \\
\hline \multirow{2}{*}{$\begin{array}{c}\text { SOD } \\
\text { (units/ml) }\end{array}$} & I & $125.07 \pm 6.19$ & $106.91 \pm 5.84$ & $106.45 \pm 5.48$ & \multirow[t]{2}{*}{0.099} & \multirow[t]{2}{*}{0.279} & \multirow[t]{2}{*}{0.242} \\
\hline & II & $121.91 \pm 7.32$ & $114.37 \pm 6.91$ & $123.31 \pm 6.48$ & & & \\
\hline \multirow{2}{*}{$\begin{array}{c}\text { MDA } \\
(\mathrm{mmol} / \mathrm{L})\end{array}$} & I & $3.12 \pm 0.05_{\mathrm{a}}$ & $2.79 \pm 0.11_{b}$ & $2.62 \pm 0.15_{b}^{A}$ & \multirow[t]{2}{*}{0.029} & \multirow[t]{2}{*}{0.145} & \multirow[t]{2}{*}{0.016} \\
\hline & II & $3.09 \pm 0.06_{\mathrm{ab}}$ & $2.92 \pm 0.13_{\mathrm{a}}$ & $3.17 \pm 0.18_{b}^{B}$ & & & \\
\hline \multirow{2}{*}{$\begin{array}{c}\text { Hb } \\
(\mathrm{g} / \mathrm{dL})\end{array}$} & I & $10.59 \pm 0.32_{c}$ & $8.59 \pm 0.39 a$ & $9.46 \pm 0.41_{b}$ & \multirow[t]{2}{*}{0.001} & \multirow[t]{2}{*}{0.426} & \multirow[t]{2}{*}{0.486} \\
\hline & II & $10.02 \pm 0.38_{c}$ & $8.00 \pm 0.46_{a}$ & $9.26 \pm 0.49 b$ & & & \\
\hline \multirow{2}{*}{$\begin{array}{c}\text { PCV } \\
(\%)\end{array}$} & I & $31.57 \pm 0.92_{a}$ & $26.87 \pm 1.15_{b}$ & $30.30 \pm 0.77_{\mathrm{a}}$ & \multirow[t]{2}{*}{0.001} & \multirow[t]{2}{*}{0.377} & \multirow[t]{2}{*}{0.987} \\
\hline & II & $30.46 \pm 1.099_{a}$ & $25.58 \pm 1.36_{b}$ & $29.22 \pm 0.91_{\mathrm{a}}$ & & & \\
\hline \multirow{2}{*}{$\begin{array}{c}\text { BUN } \\
(\mathrm{mg} / \mathrm{dL})\end{array}$} & I & $66.33 \pm 10.45$ & $58.64 \pm 8.29$ & $50.82 \pm 5.33$ & \multirow[t]{2}{*}{0.322} & \multirow[t]{2}{*}{0.320} & \multirow[t]{2}{*}{0.221} \\
\hline & II & $47.51 \pm 12.36$ & $43.28 \pm 9.81$ & $48.82 \pm 6.31$ & & & \\
\hline \multirow{2}{*}{$\begin{array}{c}\text { TP } \\
(\mathrm{mg} / \mathrm{dL})\end{array}$} & I & $7.05 \pm 0.37 \mathrm{c}^{\mathrm{B}}$ & $6.45 \pm 0.55_{b}$ & $5.14 \pm 0.55_{\mathrm{a}}$ & \multirow[t]{2}{*}{0.093} & \multirow[t]{2}{*}{0.239} & 0.006 \\
\hline & II & $5.31 \pm 0.43^{\mathrm{A}}$ & $5.14 \pm 0.66$ & $5.69 \pm 0.65$ & & & \\
\hline Albumin & I & $3.42 \pm 0.14$ & $3.19 \pm 0.19$ & $3.06 \pm 0.39$ & 0.802 & 0.643 & 0.587 \\
\hline (mg/dL) & II & $3.07 \pm 0.17$ & $2.97 \pm 0.22$ & $3.22 \pm 0.46$ & & & \\
\hline Creatinine & I & $1.17 \pm 0.16_{b}$ & $0.99 \pm 0.29 \mathrm{~b}$ & $0.48 \pm 0.09_{a}$ & 0.006 & 0.361 & 0.435 \\
\hline (mg/dL) & II & $0.77 \pm 0.19_{b}$ & $0.68 \pm 0.35_{\mathrm{ab}}$ & $0.44 \pm 0.10_{a}$ & & & \\
\hline AST & I & $136.36 \pm 16.59$ & $123.07 \pm 20.36$ & $148.33 \pm 17.02$ & 0.144 & 0.581 & 0.141 \\
\hline$(\mathbf{U} / \mathbf{L})$ & II & $145.20 \pm 19.63$ & $110.96 \pm 24.09$ & $109.44 \pm 20.14$ & & & \\
\hline ALT & I & $40.71 \pm 4.88_{b}$ & $27.79 \pm 3.08^{\mathrm{A}}$ & $29.86 \pm 5.20_{\mathrm{ab}}$ & 0.579 & 0.006 & 0.435 \\
\hline$(\mathbf{U} / \mathbf{L})$ & II & $39.60 \pm 5.77$ & $43.30 \pm 3.65^{\mathrm{B}}$ & $43.30 \pm 6.15$ & & & \\
\hline CK & I & $140.62 \pm 16.89_{a}$ & $172.02 \pm 18.30_{c}$ & $156.83 \pm 14.33_{b}$ & 0.001 & 0.150 & 0.412 \\
\hline (U/dL) & II & $171.56 \pm 19.98_{a}$ & $216.03 \pm 21.66_{b}$ & $198.83 \pm 16.95_{b}$ & & & \\
\hline Cortisol & I & $153.69 \pm 7.29 \mathrm{c}$ & $132.86 \pm 5.05_{\mathrm{b}}^{\mathrm{A}}$ & $102.62 \pm 6.92^{\mathrm{A}}$ & 0.101 & 0.001 & 0.001 \\
\hline (ng/ml) & II & $152.66 \pm 8.63$ & $152.27 \pm 5.97^{\mathrm{B}}$ & $171.06 \pm 8.19^{\mathrm{B}}$ & & & \\
\hline
\end{tabular}

Means bearing different subscripts $(a, b, c)$ differ significantly within row $(\mathrm{P}<0.05)$

Means bearing different superscripts $(\mathrm{A}, \mathrm{B})$ differ significantly within column $(\mathrm{P}<0.05)$

$\mathrm{G}=$ Group

Oxidative stress profile and haematobiochemical parameters

In present experiment, the mean TAC $(\mathrm{mmol} / \mathrm{L})$ concentration before caesarean and at $48 \mathrm{~h}$ post-caesarean did not differ significantly between group I and II (Table 2). However, TAC level after $96 \mathrm{~h}$ of caesarean section in group I was significantly $(\mathrm{P}<0.05)$ higher than group II. Further, the mean TAC concentration was significantly $(\mathrm{P}<0.05)$ increased after $48 \mathrm{~h}$ and $96 \mathrm{~h}$ of caesarean operation in group I. While, the TAC concentration did not differ significantly before and after caesarean at $96 \mathrm{~h}$ in group II. The TAC concentration was significantly $(\mathrm{P}<0.05)$ increased by $53.93 \%$ at $48 \mathrm{~h}$ and $50.56 \%$ at $96 \mathrm{~h}$ in group I. While, it was significantly $(\mathrm{P}<0.05)$ increased by $42.68 \%$ at $48 \mathrm{~h}$ and non-significantly increased by $6.10 \%$ 
at $96 \mathrm{~h}$ in group II. The mean SOD (units/ml) concentration did not differ significantly between group I and II as well as before and after caesarean operation in both the groups. The MDA concentration was significantly $(\mathrm{P}<0.05)$ reduced at $96 \mathrm{~h}$ of caesarean operation in the group I as compared to group II. Further, the MDA concentration was significantly $(\mathrm{P}<0.05)$ reduced after caesarean (48 and 96h)in the group I. In the present study, MDA concentration was significantly $(\mathrm{P}<0.05)$ reduced by $10.58 \%$ at $48 \mathrm{~h}$ and $16.03 \%$ at $96 \mathrm{~h}$ of caesarean operation in group I. While, it was non-significantly reduced at $48 \mathrm{~h}(5.50 \%)$ and increased at $96 \mathrm{~h}$ $(2.59 \%)$ in group II. Erisir et al., (2006) reported significantly higher $(\mathrm{P}<0.001)$ plasma MDA in cows with caesarean section than in the normally parturited buffaloes. They opined that caesarean section induce an inflammatory reaction associated with the occurrence of a systemic oxidative stress evidenced by the elevation of MDA concentration. The oxidative stress was not reduced in died buffaloes in the current study may be the reason for their death.

ALT concentration was significantly $(\mathrm{P}<0.05)$ reduced after $48 \mathrm{~h}$ than before the caesarean section in group I; whereas, the corresponding figures did not changed in group II. Singh et al., (2009) also found significant decrease in ALT concentration after obstetrical maneuvering as compared to before obstetrical maneuvering. The mean cortisol level was significantly $(\mathrm{P}<0.05)$ reduced at $48 \mathrm{~h}$ and $96 \mathrm{~h}$ of caesarean operation in survived buffalo group as compared to died buffalo group. Further, the concentration of cortisol was also significantly $(\mathrm{P}<0.05)$ reduced after the caesarean operation by $13.55 \%$ at $48 \mathrm{~h}$ and $33.23 \%$ at $96 \mathrm{~h}$ in group I; however, mean cortisol remained nonsignificantly higher at 96h (12.06\%) in group II throughout the study. Prabhakar et al., (1999b) and Prabhakar et al., (2002) also found significantly declined cortisol concentration in dystocia affected buffaloes.

The cortisol level was significantly $(\mathrm{P}<0.05)$ reduced in group I after $48 \mathrm{~h}$ and $96 \mathrm{~h}$ as compared to its initial level before caesarean which was in accordance with Prabhakar et al., (1999b) and Prabhakar et al., (2002). Moreover, the cortisol level was significantly $(\mathrm{P}<0.05)$ lower at $96 \mathrm{~h}$ in group I as compared to group II.

There was no significant difference in mean $\mathrm{Hb}$ and PCV level between group I and II. In contrary to present study, Verma et al., (2018) found significantly difference in $\mathrm{Hb}$ value between survived and died buffaloes after caesarean. There was no significant difference in AST, TP and albumin concentration in both the groups in the current study. The findings of the present study are in accordance with Singla and Sharma (1992) and Singh et al., (2009).

Although, Amer and Hashem (2007) found significantly higher AST level before as compared to after obstetrical treatment. The TP was not altered significantly before and after obstetrical treatment in buffaloes (Prabhakar et al., 1999a). Contrary to our findings, Chauhan et al., (2019) reported significantly higher AST level in died buffaloes as compared to survived buffaloes. The mean concentration of creatinine did not differ significantly between the groups. However, the creatinine concentration significantly $(\mathrm{P}<0.05)$ reduced after the caesarean section (96h) in both the groups.

From the above findings it was concluded that the dam survivability could be better in nonmanipulated and early presented dystocia cases in buffaloes. Further, total antioxidant capacity, malondialdehyde and cortisol can be used as prognostic indicators in caesarean operated buffaloes. 


\section{References}

Amer, H. and Hashem, A. 2007. Relationship between clinical and biochemical picture of uterine torsion in Egyptian Buffaloes (Bubalus bubalis). The Internetational Journal of Veterinary Medicine.4(1): 1-11.

Amin, S.M., Amer, H.A., Hussein, A.E. and Hazzaa, A.M. 2011. Creatine phosphokinase and aspartate aminotransverase profiles and its relation to the severity of uterine torsion in Egyptian buffalo. Animal Reproduction Science. 123: 163-168.

Bansal, A.K., Singh, A.K., Cheema, R.S., Brar, P.S., Gandotra, V.K., Singh, P. and Prabhakar, S. 2011. Status of oxidative stress and antioxidant enzymes in normally calved and dystocia affected buffaloes. Indian Journal of Animal Science. 81(9): 915918.

Chauhan, P.M., Sharma, V.K., Suthar, B., Nakhashi, H. and Sutaria, T.V. 2019. Blood plasma enzymatic profiles as predictor of post-obstetrical survival of torsion affected Mehsana buffaloes. Ruminant Science. 8(2): 181-184.

Cox, J.E. 1987. Surgery of the reproductive tract in large animals. Liverpool University Press. P: 145-170.

Dabas, V.S., Chaudhari, N.F., Chaudhari, C.F. and Bhatt R.H. 2014. Uterine torsion and its management in advanced pregnant mares. IntasPolivet. 15(II): 263-265.

Dabas, V.S., Sharma, V.K. and Chaudhari, C.F. 2013. Dystocia due to fetal anasarca coupled with amelia of one foetus in twin pregnancy in a buffalo. Buffalo Bulletin. 32(2): 83-84.

Dhindsa, S.S., Dhaliwal, G.S., Singh, H. and Ghuman, S.P.S. 2019. A retrospective study on consequences of cesarean section in bovine. International Journal of Current Microbiology and Applied Sciences. 8(1): 480-484.

Erisir, M., Akar, Y., Gurgoze, S.Y. and Yuksel, M. 2006. Changes in plasma malondialdehyde concentration and some erythrocyte antioxidant enzymes in cows with prolapsus uteri, caesarean section and retained placenta. Revue de Medecine Veterinaire. 157(2): 80-83.

Fotariya, A.A., Dalsaniya, U. R., Chaudhary, B. G., Gurjar, K. K., Chaudhari, R. K., Chaudhari, C. F. and Sutaria, T. V. 2020. Dystocia due to post-cervical uterine torsion in a Sindhi mare. International Journal of Livestock Research. 10(7): 173-177.

Gupta, R.K., Singh, V., Sachan, V., Yadav, M.K., Yadav, D.K. and Saxena, A. 2017. Two different obstetrical techniques to manage dystocia due to fetal emphysema in bovine. Indian Journal of Animal Health. 56(2): 307310.

Khudhair, N.Y., Mohammed, S. N. and Mahmood, M.Y. 2020. Some types of dystocia and their impacts on the viability of fetus in Iraqi heifer cow. Biochemical and Cellular Archives. 20(2): 4517-4521.

Murthy, K.K., Prasad, V. and Murthy, P.R.K. 1999. Clinical observations on uterine torsion in buffaloes. Indian Veterinary Journal. 76: 643-645.

Patel, G.A., Suthar, B.N., Nakhashi, H.C., Chaudhari, C.F., Sutaria, T.V. and Chaudhari, R.K. 2020. Haematobiochemical profile in goats with dystocia and retained foetal membranes. Indian Journal of Small Ruminants. 26(1): 71-74.

Prabhakar, S., Nanda, A. S. and Ghuman, S.P.S. 1999a. Prognostic importance of certain blood indices in relation to survivability of the buffaloes after obstetrical treatment. Indian Journal of Animal Reproduction. 20(2): 107-109. 
Prabhakar, S., Nanda, A. S., Ghuman, S. P. S. and Sharma, R. D. 1999b. A preliminary attempt towards modulation of stress due to obstetrical interventions in buffaloes. Indian Journal of Animal Sciences. 69 (12):1018-1019.

Prabhakar, S., Nanda, A.S. and Ghuman, S.P.S. 2002. Changes in plasma cortisol concentrations as an index of stress due to dystocia and obstetrical maneuvering in buffaloes. Indian Journal of Animal Science. 72: 309-311.

Prabhakar, S., Nanda, A.S. and Ghuman, S.P.S. 2002. Changes in plasma cortisol concentrations as an index of stress due to dystocia and obstetrical maneuvering in buffaloes. Indian Journal of Animal Science. 72: 309-311.

Purohit, G.N. and Gaur, M. 2014. Uterine torsion in buffaloes: a critical analysis. Buffalo Bulletin. 33: 4-7.

Singh, A.K., Brar, P.S. and Singla, V.K. 2009. Effect of handling different types of dystocia on minerals and biochemical profiles in dairy buffaloes. Journal of Veterinary Practitioner. 10: 116-121.

Singh, G., Pandey, A.K., Agnihotri, D., Chander, S., Chandolia, R.K. and Dutt, R. 2013. Survival and fertility rate in buffaloes following caesarean section and mutation with/without partial fetotomy. Indian Journal of Animal Science. 83(3): 251-253.
Singh, M., Dhindsa, S.S., Honparkhe, $\mathrm{M}$ and Brar, P.S. 2017. A retrospective study on survival and fertility rates following cesarean section in buffaloes. Indian Veterinary Journal. 94(10): 52- 53.

Singla, V.K. and Sharma, R.D. 1992. Serum biochemical changes associated with uterine torsion in buffaloes. The Indian Journal of Animal Reproduction. 13: 153-154.

Sloss, V. 1974. A clinical study of dystocia in cattle-I treatment. Australian Veterinary Journal. 50: 290-293.

Thangamani, A., Prasad, B.C., Srinivas, M. and Rao, K.S. 2019. Evaluation of oxidative stress in maternal dystocia affected cows (Bos indicus): A preliminary study. The Pharma Innovation Journal. 8(5): 399-402.

Traas, A.M. 2008. Surgical management of canine and feline dystocia. Theriogenology. 70(3): 337-342.

Verma, A., Chandolia, R.K., Kumar, P., Kumar, L. and Soni, N. 2018. Pre and post caesarean section haematological profile in buffaloes suffering from dystocia in relation to survival rate. The Pharma Innovation. 7(10): 705-707.

Wani, J.M., Sharma, U., Kumar, S., Ali, U., Kubra, S.S., Pandey, A.K. and Kumar, S. 2018. Dystocia in Murrah buffalo with fetal limb anomaly: a case report. Theriogenology Insight. 8(2): 91-93.

\section{How to cite this article:}

Chaudhary, B. G., C. F. Chaudhari, R. K. Chaudhari, T. V. Sutaria, B. N. Suthar, H. C. Nakhashi, P. M. Chauhan, K. K. Gurjar, S. H. Raval, S. S. Patel and Pandya, M. M. 2020. Prognostic Indices of Survivability in Caesarean Operated Buffaloes. Int.J.Curr.Microbiol.App.Sci. 9(12): 2622-2628. doi: https://doi.org/10.20546/ijcmas.2020.912.310 